\title{
TRADUCCIÓN COMENTADA DEL CUENTO “VIVER!”, DE MACHADO DE ASSIS
}

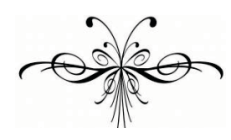

PABLO CARDELLINO SOTO

VIVER!

Fim dos tempos. Ahasverus, sentado em uma rocha, fita longamente o horizonte, onde passam duas águias cruzando-se. Medita, depois sonha. Vai declinando o dia.

Ahasverus: Chego à cláusula dos tempos; este é o limiar da eternidade. A terra está deserta; nenhum outro homem respira o ar da vida. Sou o último; posso morrer. Morrer! Deliciosa idéia! Séculos de séculos vivi, cansado, mortificado, andando sempre, mas ei-los que acabam e vou morrer com eles. Velha natureza, adeus! Céu azul, nuvens renascentes, rosas de um dia e de todos os dias, águas perennes, terra inimiga, que me não comeste os ossos, adeus! $\mathrm{O}$ errante não errará mais. Deus me perdoará, se quiser, mas a morte consola-me. Aquela montanha é áspera como a minha dor; aquelas águias, que ali passam, devem ser famintas como o meu desespero. Morrereis também, águias divinas?

Prometeu: Certo que os homens acabaram; a terra está nua deles.
¡VIVIR!

Fin de los tiempos. Ahasverus, sentado en una roca, contempla largamente el horizonte, donde pasan dos águilas que se cruzan. Medita; después sueña. Va cayendo el día.

Ahasverus: Llego a la cláusula de los tiempos; este es el umbral de la eternidad. La tierra está desierta, ningún otro hombre respira el aire de la vida. Soy el último, puedo morir. ¡Morir! ¡Deliciosa idea! Siglos de siglos viví, cansado, mortificado, caminando siempre, pero helos que terminan y moriré con ellos. Vieja naturaleza, jadiós! Cielo azul, nubes renacientes, rosas de un día y de todos los días, aguas perennes, tierra enemiga, que no me comiste los huesos, jadiós! El errante no errará más. Dios me perdonará, tal vez, pero la muerte me consuela. Aquella montaña es áspera como mi dolor; aquellas águilas que se ven pasar deben ser hambrientas como mi desesperación. ¿Moriréis también, águilas divinas?

Prometeu: Verdad que los hombres terminaron. La tierra está desnuda de ellos.

A: Ouço ainda uma voz... Voz de A: Oigo aún una voz... ¿Voz de 
homem? Céus implacáveis, não sou então o último? Ei-lo que se aproxima... Quem és tu? Há em teus grandes olhos alguma cousa parecida com a luz misteriosa dos arcanjos de Israel; não és homem...

P: Não.

\section{A: Raça divina? \\ P: Tu o disseste.}

A: Não te conheço; mas que importa que te não conheça? Não és homem; posso então morrer; pois sou o último, e fecho a porta da vida.

P: A vida, como a antiga Tebas, tem cem portas. Fechas uma, outras se abrirão. És o último da tua espécie? Virá outra espécie melhor, não feita do mesmo barro, mas da mesma luz. Sim, homem derradeiro, toda a plebe dos espíritos perecerá para sempre; a flor deles é que voltará à terra para reger as coisas. Os tempos serão retificados. O mal acabará; os ventos não espalharão mais nem os germes da morte, nem o clamor dos oprimidos, mas tão somente a cantiga do amor perene e a bênção da universal justiça...

A: Que importa à espécie que vai morrer comigo toda essa delícia póstuma? Crê-me, tu que és imortal, para os ossos que apodrecem na terra as púrpuras de Sidônia não valem nada. O que tu me contas é ainda melhor que o sonho de Campanella. $\mathrm{Na}$ cidade deste havia delitos e enfermidades; a tua exclui todas as lesões morais e físicas. O Senhor te ouça! Mas deixa-me ir morrer. hombre? Cielos implacables, ¿entonces no soy el último? Ahí se acerca... ¿Quién eres tú? Hay en tus grandes ojos alguna cosa parecida a la luz misteriosa de los arcángeles de Israel; no eres hombre...

P: No.

\section{A: ¿Raza divina? \\ P: Tú lo has dicho.}

A: No te conozco, pero ¿qué me importa no conocerte? No eres hombre; puedo así morir, pues soy el último y cierro la puerta de la vida.

P: La vida, como la antigua Tebas, tiene cien puertas. Cierras una y otras se abrirán. ¿Eres el último de tu especie? Vendrá otra especie mejor, no hecha del mismo barro, sino de la misma luz. Sí, hombre postrero, toda la plebe de los espíritus perecerá para siempre; es su flor y nata la que volverá a la tierra a regir las cosas. Los tiempos serán rectificados. El mal terminará. Los vientos no esparcirán más ni los gérmenes de la muerte ni el clamor de los oprimidos, sino tan solo el cantar del amor perenne y la bendición de la universal justicia...

A: ¿Qué le importa a la especie que muere conmigo toda esa delicia póstuma? Créeme, tú que eres inmortal, para los huesos que se pudren en la tierra las púrpuras de Sidonia no valen nada. Lo que me cuentas es aún mejor que el sueño de Campanella. En su ciudad había delitos y enfermedades, la tuya excluye todas las lesiones morales y físicas. ¡Que el Señor te oiga! Pero déjame irme a morir.

P: Vai, vai. Que pressa tens em P: Ve, ve. ¿Qué prisa tienes de 
acabar os teus dias?

A: A pressa de um homem que tem vivido milheiros de anos. Sim, milheiros de anos. Homens que apenas respiraram por dezenas deles, inventaram um sentimento de enfado, tedium vitae, que eles nunca puderam conhecer, ao menos em toda a sua implacável e vasta realidade, porque é preciso haver calcado, como eu, todas as gerações e todas as ruínas, para experimentar esse profundo fastio da existência.

\section{P: Milheiros de anos?}

A: Meu nome é Ahasverus: vivia em Jerusalém, ao tempo em que iam crucificar Jesus Cristo. Quando ele passou pela minha porta, afrouxou ao peso do madeiro que levava aos ombros, e eu empurrei-o, bradandolhe que não parasse, que não descansasse, que fosse andando até à colina, onde tinha de ser crucificado... Então uma voz anunciou-me do céu que eu andaria sempre, continuamente, até o fim dos tempos. Tal é a minha culpa; não tive piedade para com aquele que ia morrer. Não sei mesmo como isto foi. Os fariseus diziam que o filho de Maria vinha destruir a lei, e que era preciso matá-lo; eu, pobre ignorante, quis realçar o meu zelo e daí a ação daquele dia. Que de vezes vi isto mesmo, depois, atravessando os tempos e as cidades! Onde quer que o zelo penetrou numa alma subalterna, fez-se cruel ou ridículo. Foi a minha culpa irremissível.

P: Grave culpa, em verdade, mas a pena foi benévola. Os outros homens leram da vida um capítulo, tu leste o livro inteiro. Que sabe um capítulo de outro capítulo? Nada; mas o que os terminar tus días?

A: La prisa de un hombre que ha vivido millares de años. Sí, millares de años. Los hombres que sólo respiraron algunas décadas inventaron un sentimiento de fastidio, tedium vitae, que nunca pudieron conocer, al menos en toda su implacable y vasta realidad, porque es preciso haber calado, como yo, todas las generaciones y todas las ruinas para sentir ese profundo hastío de la existencia.

P: ¿Millares de años?

A: Mi nombre es Ahasverus: vivía en Jerusalén, en la época en que iban a crucificar a Jesucristo. Cuando él pasó por mi puerta, cedió un poco bajo el peso del madero que llevaba en hombros y yo lo empujé, bramando que no parara, que no descansara, que fuera caminando hasta la colina donde habría de ser crucificado... Entonces una voz me anunció desde el cielo que yo caminaría siempre, continuamente, hasta el fin de los tiempos. Esa es mi culpa; no tuve piedad de aquel que iba a morir. No sé realmente como fue. Los fariseos decían que el hijo de María venía a destruir la ley, que era preciso matarlo; yo, pobre ignorante, quise aumentar mi celo y por eso mi acto de aquel día. ¿Qué de veces vi ocurrir esto mismo, después, a través de tiempos y ciudades! Dondequiera que el celo caló en un alma subalterna, se hizo cruel o ridículo. Fue mi culpa irremisible.

P: Una grave culpa, en verdad, pero la pena fue benévola. Los otros hombres leyeron de la vida sólo un capítulo, tú leíste el libro entero. ¿Qué sabe un capítulo de otro 
leu a todos, liga-os e conclui. Há páginas melancólicas? Há outras joviais e felizes. À convulsão trágica precede a do riso, a vida brota da morte, cegonhas e andorinhas trocam de clima, sem jamais abandoná-lo inteiramente; é assim que tudo se concerta e restitui. Tu viste isso, não dez vezes, não mil vezes, mas todas as vezes; viste a magnificência da terra curando a aflição da alma, e a alegria da alma suprindo à desolação das cousas; dança alternada da natureza, que dá a mão esquerda a Jó e a direita a Sardanapalo.

A: Que sabes tu da minha vida? Nada; ignoras a vida humana.

P: Ignoro a vida humana? Deixa-me rir! Eia, homem perpétuo, explica-te. Conta-me tudo; saíste de Jerusalém...

A: Saí de Jerusalém. Comecei a peregrinação dos tempos. Ia a toda parte, qualquer que fosse a raça, o culto ou a língua; sóis e neves, povos bárbaros e cultos, ilhas, continentes, onde quer que respirasse um homem aí respirei eu. Nunca mais trabalhei. Trabalho é refúgio, e não tive esse refúgio. Cada manhã achava comigo a moeda do dia... Vede; cá está a última. Ide, que já não sois precisa (atira a moeda ao longe). Não trabalhava, andava apenas, sempre, sempre, sempre, um dia e outro dia, um ano e outro ano, e todos os anos, e todos os séculos. A eterna justiça soube o que fez: somou a eternidade com a ociosidade. As gerações legavam-me umas às outras. As línguas que morriam ficavam com o meu nome embutido na ossada. Com o volver dos tempos, esquecia-se tudo; os capítulo? Nada; pero quien los ha leído todos, los ata y concluye. ¿Hay páginas melancólicas? Hay otras joviales y felices. A la convulsión trágica precede la de la risa, la vida brota de la muerte, las cigüeñas y las golondrinas cambian de clima, sin abandonarlo nunca por completo; es así que todo se acomoda y restituye. Tú lo viste no diez veces, no mil veces, sino todas las veces. Viste la magnificencia de la tierra curando la aflicción del alma, y la alegría del alma supliendo a la desolación de las cosas; danza alternada de la naturaleza, que le da la mano izquierda a Jo y la derecha a Sardanápalo.

A: ¿Qué sabes tú de mi vida? Nada, ignoras la vida humana.

P: ¿Ignoro la vida humana? ¡Hazme reír! ¡Ea, hombre perpetuo, explícate! Cuéntamelo todo: saliste de Jerusalén...

A: Salí de Jerusalén. Empecé la peregrinación de los tiempos. Iba a todas partes, cualquiera fuera la raza, el culto o la lengua. Soles y nieves, pueblos bárbaros y cultos, islas, continentes, dondequiera que respirara un hombre, allí respiraba yo. Nunca más trabajé. El trabajo es un refugio, y no tuve ese refugio. Cada mañana me veía con la moneda del día... Ved, aquí está la última. Idos, que ya no sois precisa (la tira lejos). No trabajaba, sólo caminaba, siempre, siempre, siempre, un día y otro día, un año y otro año, y todos los años, y todos los siglos. La eterna justicia supo lo que hizo: sumó la eternidad al ocio. Las generaciones me legaban las unas a las otras. Las lenguas que morían se quedaban con mi nombre incrustado en los huesos. Con el curso de los tiempos se olvidaba 
heróis dissipavam-se em mitos, na penumbra, ao longe; e a história ia caindo aos pedaços, não lhe ficando mais que duas ou três feições vagas e remotas. E eu via-as de um modo e de outro modo. Falaste em capítulo? Felizes os que só leram a vida em um capítulo. Os que se foram, à nascença dos impérios, levaram a impressão da perpetuidade deles; os que expiraram quando eles decaíam, enterraram-se com a esperança da recomposição; mas sabes tu o que é ver as mesmas cousas, sem parar, a mesma alternativa de prosperidade e desolação, desolação e prosperidade, eternas exéquias e eternas aleluias, auroras sobre auroras, ocasos sobre ocasos?

P: Mas não padeceste, creio; é alguma cousa não padecer nada.

A: Sim, mas vi padecer os outros homens, e, para o fim, o espetáculo da alegria dava-me a mesma sensação que os discursos de um doido. Fatalidades do sangue e da carne, conflitos sem fim, tudo vi passar a meus olhos, a ponto que a noite me fez perder o gosto ao dia, e acabo não distinguindo as flores das urzes. Tudo se me confunde na retina enfarada.

P: Pessoalmente não te doeu nada; e eu que padeci por tempos inúmeros o efeito da cólera divina?

A: Tu?

P: Prometeu é o meu nome.

A: Tu Prometeu? todo; los héroes se disipaban en mitos, en la penumbra, a lo lejos, y la historia iba cayendo a pedazos, sin que le restaran más de dos o tres facciones vagas y remotas. $\mathrm{Y}$ yo las veía de uno y de otro modo. ¿Dijiste capítulo? Felices los que sólo leyeron la vida en un capítulo. Los que se fueron, al nacer los imperios, se llevaron la impresión de su perpetuidad; los que expiraron cuando decaían fueron enterrados con la esperanza da la recomposición; ¿pero sabes tú lo que es ver las mismas cosas, sin parar, la misma alternativa de prosperidad $y$ desolación, desolación y prosperidad, eternas exequias y eternas aleluyas, auroras tras auroras, ocasos tras ocasos?

P: Pero no padeciste, creo; ya es algo no padecer nada.

A: Sí, pero vi padecer a los otros hombres, y, hacia el final, el espectáculo de la alegría me daba la misma sensación que los discursos de un loco. Fatalidades de la sangre y de la carne, conflictos sin fin, todo lo vi pasar a mis ojos, al punto de que la noche me hizo perderle el gusto al día y acabo por no distinguir las flores de las matas. Todo se me confunde en la retina asqueada.

P: Personalmente no te dolió nada, ¿y yo, que padecí tiempos innúmeros el efecto de la cólera divina?

A: ¿'Tú?

P: Prometeo es mi nombre.

A: ¿'Tú, Prometeo? 
P: E qual foi o meu crime? Fiz de lodo e água os primeiros homens, e depois, compadecido, roubei para eles o fogo do céu. Tal foi o meu crime. Júpiter, que então regia o Olimpo, condenou-me ao mais cruel suplício. Anda, sobe comigo a este rochedo.

A: Contas-me uma fábula. Conheço esse sonho helênico.

P: Velho incrédulo! Anda ver as próprias correntes que me agrilhoaram; foi uma pena excessiva para nenhuma culpa; mas a divindade orgulhosa e terrível... Chegamos, olha, aqui estão elas...

A: O tempo que tudo rói não as quis então?

P: Eram de mão divina; fabricou-as Vulcano. Dois emissários do céu vieram atar-me ao rochedo, e uma águia, como aquela que lá corta o horizonte, comia-me o fígado, sem consumi-lo nunca. Durou isto tempos que não contei. Não, não podes imaginar este suplício...

A: Não me iludes? Tu Prometeu? Não foi então um sonho da imaginação antiga?

P: Olha bem para mim, palpa estas mãos. Vê se existo.

A: Moisés mentiu-me. Tu Prometeu, criador dos primeiros homens?

P: Foi o meu crime.

A: Sim, foi o teu crime, artífice do inferno; foi o teu crime inexpiável. Aqui devias ter ficado por todos os tempos, agrilhoado e devorado, tu, origem dos males que me afligiram. Careci de piedade, é certo; mas tu,
P: ¿Y qué se me imputa? Hice de lodo y agua a los primeros hombres y después, compadecido, robé para ellos el fuego del cielo. Ese fue mi crimen. Júpiter, que entonces regía el Olimpo, me condenó al más cruel suplicio. Ven, sube conmigo a este peñasco.

A: Me cuentas una fábula. Conozco ese sueño helénico.

P: ¡Viejo incrédulo! Ven a ver las mismas cadenas que me engrillaron. Fue una pena excesiva para ninguna culpa, pero la divinidad orgullosa y terrible... Llegamos, mira, aquí están...

A: ¿El tiempo, que tolo lo roe, no las quiso entonces?

P: Eran de mano divina, las fabricó Vulcano. Dos emisarios del cielo vinieron a atarme al peñasco y un águila, como aquella que ves cruzando el horizonte, me comía el hígado, sin consumirlo nunca. Eso duró tiempos que no conté. No, no te puedes imaginar ese suplicio...

A: ¿No me mientes? ¿'Tú Prometeo? $¿$ No fue entonces un sueño de la imaginación antigua?

P: Mírame bien, palpa estas manos. Fíate si existo.

A: Moisés me mintió. ¿'Tú Prometeo, creador de los primeros hombres?

P: Fue mi crimen.

A: Sí, fue tu crimen, artífice del infierno; fue tu crimen inexpiable. Aquí debieras haberte quedado por todos los tiempos, engrillado y devorado, tú, origen de los males que me afligieron. Carecí de piedad, es 
que me trouxeste à existência, verdad; pero tú, que me trajiste a la divindade perversa, foste a causa existencia, divinidad perversa, fuiste original de tudo.

la causa original de todo.

P: A morte próxima obscurece-te a razão.

P: La muerte cercana te nubla la razón.

A: Sim, és tu mesmo, tens a fronte olímpica, forte e belo titão: és tu mesmo... São estas as cadeias? Não vejo o sinal das tuas lágrimas.

A: Sí, eres tú mismo, tienes la frente olímpica, fuerte y bello titán: eres tú mismo... ¿Son estas las cadenas? No veo rastros de tus lágrimas.

P: Chorei-as pela tua raça.

P: Las lloré por tu raza.

A: Ela chorou muito mais por tua culpa.

P: Ouve, último homem, último ingrato!

P: ¡Óyeme, último hombre, último ingrato!

A: Para que quero eu palavras tuas? Quero os teus gemidos, divindade perversa. Aqui estão as cadeias. Vê como as levanto nas mãos; ouve o tinir dos ferros... Quem te desagrilhoou outrora?

A: ¿Para qué querría yo palabras tuyas? Quiero tus gemidos, divinidad perversa. Aquí están las cadenas. Mira como las levanto en mis manos, oye el ruido de los hierros...¿Quién te desherró otrora?

\section{P: Hércules.}

P: Hércules.

A: Hércules... Vê se ele te presta igual serviço, agora que vais ser novamente agrilhoado.

\section{P: Deliras.}

A: Hércules... Trata de que te preste el mismo servicio, ahora que serás engrillado nuevamente.

P: Deliras.

A: O céu deu-te o primeiro castigo; agora a terra vai dar-te o segundo e derradeiro. Nem Hércules poderá mais romper estes ferros. Olha como os agito no ar, à maneira de plumas; é que eu represento a força dos desesperos milenários. Toda a humanidade está em mim. Antes de cair no abismo, escreverei nesta pedra o epitáfio de um mundo. Chamarei a águia, e ela virá; dir-lhe-ei que o derradeiro homem, ao partir da vida, deixa-lhe um regalo de deuses.

A: El cielo te dio el primer castigo; ahora la tierra te dará el segundo y último. Ni Hércules podrá romper más estos hierros. Fíjate cómo los sacudo en el aire, a modo de plumas; es que yo represento la fuerza de los desesperos milenarios. Toda la humanidad está en mí. Antes de caer al abismo, escribiré en esta piedra el epitafio de un mundo. Llamaré al águila y ella vendrá. Le diré que el último hombre, al partir de la vida, le deja un regalo de dioses. 
P: Pobre ignorante, que rejeitas um trono! Não, não podes mesmo rejeitá-lo.

A: És tu agora que deliras. Eia, prostra-te, deixa-me ligar-te os braços. Assim, bem, não resistirás mais; arqueja para aí. Agora as pernas...

P: Acaba, acaba. São as paixões da terra que se voltam contra mim; mas eu, que não sou homem, não conheço a ingratidão. Não arrancarás uma letra ao teu destino, ele se cumprirá inteiro. Tu mesmo serás o novo Hércules. Eu, que anunciei a glória do outro, anuncio a tua; e não serás menos generoso que ele.

\section{A: Deliras tu?}

P: A verdade ignota aos homens é o delírio de quem a anuncia. Anda, acaba.

A: A glória não paga nada, e extingue-se.

P: Esta não se extinguirá. Acaba, acaba; ensina ao bico adunco da águia como me há de devorar a entranha; mas escuta... Não, não escutes nada; não podes entender-me.

\section{A: Fala, fala.}

P: O mundo passageiro não pode entender o mundo eterno; mas tu serás o elo entre ambos.

\section{A: Dize tudo.}

P: Não digo nada; anda, aperta bem estes pulsos, para que eu não fuja, para que me aches aqui à tua volta. Que te diga tudo? Já te disse que uma raça nova povoará a terra, feita dos
P: ¡Pobre ignorante, que rechazas un trono! No, no puedes rechazarlo realmente.

A: Eres tú el que ahora delira. ¡Ea!, póstrate, déjame atarte los brazos. Así, bien, no te resistirás más, arquéate hacia ahí. Ahora las piernas...

P: Acaba, acaba. Las pasiones de la tierra se me vuelven en contra; pero yo, que no soy hombre, no conozco la ingratitud. No le arrancarás una letra a tu destino, se cumplirá por entero. Tú mismo serás el nuevo Hércules. Yo, que anuncié la gloria del otro, anuncio la tuya; y no serás menos generoso que él.

A: ¿Estás delirando?

P: La verdad ignorada por los hombres es el delirio de quien la anuncia. Anda, acaba.

A: La gloria no paga nada, y se extingue.

P: Esta no se extinguirá. Acaba, acaba, enséñale al pico encorvado del águila cómo me debe devorar las entrañas, pero escucha... No, no escuches nada, no puedes entenderme.

A: Dime, dime.

P: El mundo pasajero no puede entender al mundo eterno, pero tú serás el eslabón entre ambos.

A: Dilo todo.

P: No digo nada. Anda, apriétame bien los pulsos para que no huya, para que me encuentres aquí a la vuelta. ¿Qué te lo diga todo? Ya te dije que una raza nueva poblará la 
melhores espíritos da raça extinta; a multidão dos outros perecerá. Nobre família, lúcida e poderosa, será perfeita comunhão do divino com o humano. Outros serão os tempos, mas entre eles e estes um elo é preciso, e esse elo és tu.

\section{A: Eu?}

P: Tu mesmo, tu eleito, tu, rei. Sim, Ahasverus, tu serás rei. O errante pousará. O desprezado dos homens governará os homens.

A: Titão artificioso, iludes-me... Rei, eu?

P: Tu rei. Que outro seria? O mundo novo precisa de uma tradição do mundo velho, e ninguém pode falar de um a outro como tu. Assim não haverá interrupção entre as duas humanidades. $\mathrm{O}$ perfeito procederá do imperfeito, e a tua boca dir-lhe-á as suas origens. Contarás aos novos homens todo o bem e todo o mal antigo. Reviverás assim como a árvore a que cortaram as folhas secas, e conserva tão-somente as viçosas; mas aqui o viço é eterno.

\section{A: Visão luminosa! Eu mesmo?}

P: Tu mesmo.

A: Estes olhos... estas mãos... vida nova e melhor... Visão excelsa! Titão, é justo. Justa foi a pena; mas igualmente justa é a remissão gloriosa do meu pecado. Viverei eu? eu mesmo? Vida nova e melhor? Não, tu mofas de mim.

P: Bem, deixa-me, voltarás um dia, quando este imenso céu for aberto para que desçam os espíritos da vida tierra hecha con los mejores espíritus de la raza extinta. La muchedumbre de los otros perecerá. Noble familia, lúcida y poderosa, será una perfecta comunión de lo divino con lo humano. Otros serán los tiempos, pero entre ellos y estos un eslabón es preciso, y el eslabón eres tú.

A: ¿Yo?

P: Tú mismo, tú electo, tú, rey. Sí, Ahasverus, tú serás rey. El errante descansará. El despreciado de los hombres gobernará a los hombres.

A: Titán astuto, te burlas de mí... ¿Rey, yo?

P: Tú, rey. ¿Qué otro sería? El mundo nuevo precisa una tradición del mundo viejo, y nadie puede hablarle del uno al otro como tú. Así no habrá interrupción entre las dos humanidades. Lo perfecto procederá de lo imperfecto, y tu boca le dirá sus orígenes. Les contarás a los nuevos hombres todo el bien y todo el mal antiguo. Revivirás así como el árbol al que le cortaron las hojas secas y conserva tan sólo las lozanas, pero aquí la lozanía es eterna.

A: ¡Visión luminosa! ¿Yo mismo?

P: Tú mismo.

A: Estos ojos... estas manos... vida nueva y mejor... ¡Visión excelsa! Titán, es justo. Justa fue la pena, pero igualmente justa es la remisión gloriosa de mi pecado. ¿Viviré? ¿Yo mismo? ¿Vida nueva y mejor? No, te burlas de mí.

P: Bien, déjame, volverás un día, cuando este inmenso cielo azul se abra para que bajen los espíritus de la vida nueva. Aquí me encontrarás 
nova. Aqui me acharás tranqüilo. Vai.

tranquilo. Vete.

A: Saudarei outra vez o sol?

P: Esse mesmo que ora vai a cair. Sol amigo, olho dos tempos, nunca mais se fechará a tua pálpebra. Fita-o, se podes.

\section{A: Não posso.}

P: Podê-lo-ás depois quando as condições da vida houverem mudado. Então a tua retina fitará o sol sem perigo, porque no homem futuro ficará concentrado tudo o que há melhor na natureza, enérgico ou sutil, cintilante ou puro.

A: Jura que me não mentes.

P: Verás se minto.

A: Fala, fala mais, conta-me tudo.

P: A descrição da vida não vale a sensação da vida; tê-la-ás prodigiosa. O seio de Abraão das tuas velhas Escrituras não é senão esse mundo ulterior e perfeito. Lá verás David e os profetas. Lá contarás à gente estupefata não só as grandes ações do mundo extinto, como também os males que ela não há de conhecer, lesão ou velhice, dolo, egoísmo, hipocrisia, a aborrecida vaidade, a inopinável toleima e o resto. A alma terá, como a terra, uma túnica incorruptível.

A: Verei ainda este imenso céu azul!

P: Olha como é belo.

A: Belo e sereno como a eterna justiça. Céu magnífico, melhor que as tendas de Cedar, ver-te-ei ainda e
A: ¿Saludaré otra vez al sol?

P: Ese mismo que ahora se pone. Sol amigo, ojo de los tiempos, nunca más se cerrará ante tu párpado. Míralo si puedes.

A: No puedo.

P: Podrás hacerlo después cuando las condiciones de vida hayan cambiado. Entonces tu retina mirará el sol sin peligro, porque en el hombre futuro se concentrará todo lo mejor de la naturaleza, enérgico o sutil, resplandeciente o puro.

A: Júrame que no me mientes.

P: Si miento lo verás.

A: Habla, háblame más, cuéntamelo todo.

P: La descripción de la vida no vale la sensación de la vida, y la tendrás prodigiosa. El seno de Abraham de tus viejas Escrituras no es sino ese mundo ulterior y perfecto. En él verás a David y a los profetas. En él le contarás a la gente estupefacta no sólo las grandes acciones del mundo extinto sino también los males que ella no va a conocer, lesión o vejez, dolo, egoísmo, hipocresía, la fastidiosa vanidad, la inopinable necedad y el resto. El alma tendrá, así como la tierra, una túnica incorruptible.

A: ¡Veré aún este inmenso cielo azul!

P: Mira qué bello es.

A: Bello y sereno como la eterna justicia. Cielo magnífico, mejor que las carpas de Quedar, te veré aún y 
sempre; tu recolherás os meus siempre. Tú cosecharás mis pensamentos, como outrora; tu me pensamientos, como otrora, tú me darás os dias claros e as noites darás los días claros y las noches amigas...

P: Auroras sobre auroras. amigas...

A: Eia, fala, fala mais. Conta-me A: ¡Ea, habla, háblame más. tudo. Deixa-me desatar-te estas Cuéntamelo todo. Déjame desatarte cadeias... estas cadenas...

P: Desata-as, Hércules novo, homem derradeiro de um mundo, que vás ser o primeiro de outro. É o teu destino; nem tu nem eu, ninguém poderá mudá-lo. És mais ainda que o teu Moisés. Do alto do Nebo, viu ele, prestes a morrer, toda a terra de Jericó, que ia pertencer à sua posteridade; e o Senhor lhe disse: "Tu a viste com teus olhos, e não passarás a ela." Tu passarás a ela, Ahasverus; tu habitarás Jericó.

A: Põe a mão sobre a minha cabeça, olha bem para mim; incute-me a tua realidade e a tua predição; deixa-me sentir um pouco da vida nova e plena... Rei disseste?

P: Rei eleito de uma raça eleita.

P: Desátalas, Hércules nuevo, hombre último de un mundo, que vas a ser el primero de otro. Ese es tu destino; ni tú ni yo, nadie podrá cambiarlo. Eres más aún que tu Moisés. De lo alto del Nebo, vio él, a punto de morir, toda la tierra de Jericó, que iba a pertenecer a su posteridad. Y el Señor le dijo: "Tú la viste con tus ojos, y no pasarás a ella." Tú pasarás a ella, Ahasverus; tú habitarás Jericó.

A: Ponme la mano sobre la cabeza, mírame bien; infúndeme tu realidad y tu predicción; déjame sentir un poco de la vida nueva y plena... ¿Rey, dijiste?

P: Rey electo de una raza electa.

A: Não é demais para resgatar o profundo desprezo em que vivi. Onde uma vida cuspiu lama, outra vida porá uma auréola. Anda, fala mais... fala mais... (Continua sonhando. As duas águias aproximam-se.)

A: No es demasiado para rescatar el profundo desprecio en que viví. Donde una vida escupió barro, otra vida se pondrá una aureola. Anda, habla más... habla más... (Continúa soñando. Las dos águilas se aproximan.)

Á1: Ai, ai, ai deste último homem, Á1: ¡Ay, ay, ay de este último está morrendo e ainda sonha com a hombre! ¡Está muriendo y aún sueña vida. con la vida!

Á2: Nem ele a odiou tanto, senão porque a amava muito.

Á2: Él no la odió tanto sino porque la amaba mucho. 


\section{Comentarios}

"Viver!", que fue publicado en Várias histórias en 18861 , es un cuento que se encuadra más bien en lo maravilloso que en lo fantástico, ${ }^{2}$ pues narra el diálogo entre Ahasverus, ${ }^{3}$ el último de los hombres al final de la eternidad, con Prometeo. La introducción en un tiempo mítico y la presencia indiscutida de acontecimientos imposibles según las leyes naturales de nuestro mundo - como la voz de Dios abriéndose paso entre los cielos, la misma existencia de un hombre vivo hace millares de años, etc. - son aspectos insoslayables del cuento. En el espacio-tiempo del cuento, universo de los personajes, sin embargo, la realidad de esos hechos no se cuestiona. ${ }^{4}$

Este cuento presenta una forma peculiar: la de una pieza dramática, con ausencia de un narrador explícito, excepto al principio, donde en sólo tres líneas describe la situación inicial y da todos los detalles claves de la diégesis: sitúa el relato en el "fim dos tempos"; presenta a Ahasverus, que está con los ojos clavados en el horizonte — que sin dudas es metáfora de su vida, cuyo fin nunca puede alcanzar por más que camine_-; menciona a las dos águilas que cruzan el horizonte - lo que las sitúa en la diégesis-; afirma que él "medita, depois sonha" - sueño del que no sale, despertando algunas dudas de poca importancia sobre si el diálogo final entre las águilas ocurre en el mismo plano diegético del narrador o en el sueño de Ahasverus, y sobre si él efectivamente despierta-; y culmina diciendo que "vai declinando o dia", es decir, se llega al momento en que el horizonte desaparece: terminando el día, al fin de los tiempos, terminan los tiempos. A partir de aquí, Ahasverus hace su monólogo inicial, cuando sale Prometeo y ambos entablan el diálogo que se extiende hasta el final. Durante el diálogo, el narrador se infiltra de forma sutil, por momentos, en los parlamentos de ambos personajes —o tal vez se podría decir que los personajes suplen el silencio del narrador - para dar detalles de la acción — circundante o de los mismos personajes-:

Ahasverus._- Ouço ainda uma voz... Voz de homem? Céus implacáveis, não sou então o último? Ei-lo que se aproxima... Quem és tu? ${ }^{5}$ ( $\left(4^{6}\right)$

\footnotetext{
${ }^{1}$ Esa es la primera publicación en libro. Utilizo para este trabajo la edición de Várias histórias de W. M. Jackson Editores de 1937.

${ }^{2}$ Según la visión de lo Fantástico defendida por Todorov (1981).

${ }^{3}$ Según Câmara Cascudo (1954) la leyenda de Ahasverus, el judío errante, apareció en Constantinopla en el S. IV, y apareció en Europa en 1228, traída por un arzobispo Armenio que visitaba Inglaterra. Cascudo relata que Ahasverus
}

era sapateiro em Jerusalém, [...] quando Nosso Senhor, com a cruz aos ombros, passou diante de sua tenda. O sapateiro deixou o trabalho para empurrar o Salvador, gritando: "Vai andando! Vai logo!" Nosso Senhor respondeu: "Eu vou e tu ficarás até a minha volta!” E o homem ficou, até hoje, andando pelo mundo, liberto da lei da morte, sem pressa e sem descanso. Espera o regresso do Senhor, que lhe deu a imortal penitência. A tradição nos veio de Portugal. (CASCUDO, 1954.)

\footnotetext{
${ }^{4}$ Es esta no problematización lo que sitúa el cuento en lo maravilloso según Barrenechea (1972).

${ }^{5}$ Subrayados míos en las citas del cuento, a menos que indique lo contrario.
} 


\begin{abstract}
Ahasverus. - Para que quero eu palavras tuas? Quero os teus gemidos, divindade perversa. Aqui estão as cadeias. $V \hat{e}$ como as levanto nas mãos; ouve o tinir dos ferros... Quem te desagrilhoou outrora? (\40)

Prometeu.- Dois emissários do céu vieram atar-me ao rochedo, e uma águia, como aquela que lá corta o horizonte, comia-me o fígado, sem consumi-lo nunca. (\$ 29)
\end{abstract}

El narrador también vuelve aparecer explícitamente en un par de situaciones, con breves descripciones de acción, entre paréntesis y en itálico, como es habitual en las obras destinadas a la representación dramática:

Cada manhã achava comigo a moeda do dia... Vede; cá está a última. Ide, que já não sois precisa (atira a moeda ao longe).

\title{
Aspectos de la traducción
}

Para discutir los asuntos relacionados con la traducción intenté, a fin de hacer posible un cotejo, localizar alguna traducción previa del cuento, y llegué a una edición de Varias Historias traducida al español por Rafael Mesa López y publicada en París por Garnier Hnos. en algún momento de principios del S. XX, posiblemente en la segunda década. ${ }^{7}$ Todos los aspectos de la traducción de este cuento que presento serán distribuidos gráficamente en tres columnas, correspondiendo, en este orden, al original, a mi traducción y a la de Mesa.

En lo que se refiere al género, híbrido entre el cuento y el drama, además de la asunción de la narración de algunas circunstancias por parte de los personajes, Ahasverus se dirige en cierto momento a un interlocutor, singular o plural, que puede no ser Prometeo:

Original

Cada manhã achava comigo a moeda do dia... Vede; cá está a última. Ide, que já não sois precisa (atira a moeda ao longe)..$^{8}(\mathbb{1} 18)$

\section{Cardellino}

Cada mañana me veía con la moneda del día... Ved, aquí está la última. Idos, que ya no sois precisa (la tira lejos). ( $(\$ 18)$

\section{Mesa}

Cada mañana hallaba la moneda del día; esta es la última. ¡ Largo de aquí, ya no me sirve! (La arroja lejos). (p. $\left.200^{9}\right)$

Hay que notar que Ahasverus tutea a Prometeo. Sin embargo, aquí dice "Vede", conjugación del verbo "ver" correspondiente a "vós" en imperativo, que podría ser una forma de tratamiento destinada a Prometeo (asumiendo que

\footnotetext{
${ }^{6}$ En vista de que incluyo la versión original del cuento, lo citaré por número de párrafo, sin detrimento del origen mencionado.

${ }^{7}$ Rafael Mesa López firma la traducción de Dom Casmurro publicada en 1911 también por Garnier.

${ }^{8}$ La oración entre paréntesis está en itálico en el cuento y en ambas traducciones.

${ }^{9}$ Todas las páginas de la traducción de Mesa se refieren a la mencionada edición de Varias historias de Garnier.
} 
hubiera alguna inconsistencia de tratamiento) o a otro interlocutor, pero que también es una forma de segunda persona del plural. Es decir, de acuerdo con el formato de obra teatral, es dable interpretar este "vós" como el público implícito. Eso refuerza lo ostensivo de la acción, donde todo llama la atención y confluye hacia la moneda. Es un momento de mucha fuerza dramática, donde el personaje ya se está deshaciendo de su humanidad. En ese momento, Ahasverus vosea a la misma moneda, lo que establece un paralelismo ineludible con respecto al "vede" anterior, que causa una cierta turbulencia en el texto, muy enriquecedora, por cierto, ya que la presunta ruptura de la cuarta pared del escenario imaginario resulta dudosa. En ese momento del texto no hay certezas. La traducción de Mesa no considera ese paso, que pierde su fuerza expresiva y dramática, su imaginería.

En cuanto al estilo, en la traducción de este cuento intenté mantener el tono "desusado" del texto, en ocasiones arcaizante, un tono que, creo, transmite la sensación de que ese texto es fuera de lo común. Este tono es importante para la narrativa pues un tono actual, corriente, conspiraría contra el origen temporal de los personajes —un tiempo ahistórico en el caso de Prometeo, la época de Jesús en el de Ahasverus - y también contra el tiempo de la narrativa, que se sitúa en el futuro más lejano posible: el fin de los tiempos. Esta característica del texto se percibe de dos modos distintos: en algunas opciones de vocabulario -ora palabras de uso escaso, ora giros o colocaciones extraordinarios- y en algunos hábitos textuales recurrentes en Machado, pero que en conjunto hacen que el texto tenga un sabor algo exótico, que asocio a esa situación fuera de nuestro tiempo.

En los siguientes fragmentos se muestran algunos ejemplos relacionados con las opciones textuales inusuales:

\section{Original}

Chego à cláusula dos tempos; [...] (§)

Séculos de séculos vivi, cansado, mortificado, andando sempre, mas ei-los que acabam e vou morrer com eles. (\$ 2)

Aquelas águias, que ali passam, devem ser famintas como o meu desespero. ( ( 2 )

Que de vezes vi isto mesmo, depois,

\section{Cardellino}

Llego a la cláusula de los tiempos; [...] ( ( 2 )

Siglos de siglos viví, cansado, mortificado, caminando siempre, pero helos que terminan y moriré con ellos. (\$ 2)

aquellas águilas que se ven pasar deben ser hambrientas como mi desesperación. (\2)

¿Qué de veces vi ocurrir esto mismo,

\section{Mesa}

Llegó el fin de los tiempos. (p. 197)

He vivido siglos de siglos, cansado, mortificado, siempre andando. He ahí los que acaban : voy á morir con ellos. (p. 197)

aquellas águilas que pasan deben estar hambrientas. (p. 197)

i Cuántas veces he visto esto mismo en 
atravessando os tempos e as cidades! ( $\int$ 14)

Foi a minha culpa irremissível. (\ 14)

Quem te desagrilhoon outrora? (\40) después, a través de tiempos y ciudades! ( $\mathbb{S}$ 14)

Fue mi culpa irremisible. (\ 14)

¿Quién te desherró otrora? (\$ 40) los pueblos y las

ciudades! (p. 199)

[Omisión] (p. 199)

¿Quién te libró de ellas? (p. 202)

Algunos de estos usos son sutiles, como usar "ser" en vez de "estar" junto a "famintas", saliendo de la colocación ${ }^{10}$ más corriente, "estar famintas" para la menos corriente, "ser famintas" — que conlleva la noción de estado permanente, y por lo tanto se refiere a un hambre espiritual, algo que se le escapa a Mesa-, o la inversión de términos de la oración, que en orden directo sería "a minha culpa foi irremissível".

En mi traducción intenté tomar en cuenta la presencia de estas características del texto y, en la medida de lo posible, mantenerlas. En ese sentido las opciones literales se mostraron muy útiles. Por literales me refiero a opciones que se mantienen lo más cerca posible del original. Esto, en la traducción portuguésespañol es posible en un grado bastante elevado debido, naturalmente, a la proximidad de ambas lenguas. "Lo más cerca posible" significa usar las mismas estructuras y las formas españolas de las mismas palabras hasta el punto en que se sale de lo gramaticalmente correcto y se pasa a la interferencia, un punto que no siempre está demasiado claro. En ocasiones, esto puede implicar usos lingüísticos un poco menos naturales en español. Si bien en otros tipos de textos o con otro marco teórico la extrañeza que dichos usos pueden causar pudiera ser un anti-valor, en éste ayudó precisamente a la manutención de ese tono. De un modo general, Mesa se inclinó mucho más, en sus opciones, por una mediación y una facilitación, eliminando buena parte de ese tono "desusado" del texto. Los errores que ocurren en su traducción, como al traducir "ei-los", hacen pensar en una no muy grande intimidad del traductor con el portugués. Esto puede explicar la actitud exegética del traductor, que tal vez se sienta inclinado a simplificar un poco el texto en virtud de las dificultades de lectura que enfrenta. Sin embargo, independientemente de sus motivos, cabe analizar críticamente el texto, y lo que cuenta en este caso es la diferente cualidad del texto traducido respecto del original, en lo que se refiere a lo inusual de las opciones textuales de Machado. Un ejemplo extremo de esta actitud exegética (extremo porque supera lo estrictamente exegético, llegando al resumen) se puede ver en el siguiente fragmento, que aunque es parte de un solo párrafo (\$ 15; p. 199 en la traducción de Mesa) yo lo separé en partes menores para un cotejo más claro:

\footnotetext{
${ }^{10}$ Según Stella Tagnin, "el término collocation fue introducido por el lingüista escocés J. R. Firth para designar casos de coocurrencia léxico-sintáctica, es decir, palabras que usualmente "están juntas"” (TAGNIN apud Guerini y Costa, 2006. Traducción mía).
} 
Original

Os outros homens leram da vida um capítulo, tu leste o livro inteiro.

Que sabe um capítulo de outro capítulo?

Nada;

mas o que os leu a todos, liga-os e conclui.

Há páginas melancólicas?

Há outras joviais e felizes.

À convulsão trágica precede a do riso, a vida brota da morte, cegonhas e andorinhas trocam de clima, sem jamais abandoná-lo inteiramente;

é assim que tudo se concerta e restitui.

Tu viste isso, não dez vezes, não mil vezes, mas todas as vezes;

\section{Cardellino}

Los otros hombres leyeron de la vida sólo un capítulo, tú leíste el libro entero.

¿Qué sabe un capítulo de otro capítulo?

Nada;

pero quien los ha leído todos, los ata y concluye.

¿Hay melancólicas?

Hay otras joviales y felices.

A la convulsión trágica precede la de la risa, la vida brota de la muerte, las cigüeñas y las golondrinas cambian de clima, sin abandonarlo nunca por completo;

es así que todo se acomoda y restituye.

Tú lo viste no diez veces, no mil veces, sino todas las veces.
Tú viste lo trágico preceder a la risa más de diez $\mathrm{y}$ cien veces, todas las veces.

Todo el trabajo textual de Machado fue simplemente desechado en este fragmento de la traducción de Mesa, que rescata únicamente las partes necesarias para la transmisión del significado, repitiendo la oposición trágico-risa repetición de la que no se vale Machado-, y dejando indicios de no haber comprendido la sintaxis invertida de "à convulsão trágica precede a do riso", que, en su contexto, es muestra de la versatilidad textual de Machado.

Estos breves comentarios, que no pretenden ser exhaustivos, ponen de relieve la complejidad del texto de Machado a través de la discusión de algunos de los desafíos concretos que le presenta al traductor, en particular algunos de los aspectos formales que se revelaron importantes para la construcción de la narrativa. 
Bajo esta perspectiva, resulta evidente la conveniencia de la propuesta de Berman: asumir la traducción como traducción de la letra (BERMAN, 2007). De hecho, todos los aspectos formales que discutí son trabajados dentro del marco de una traducción de la letra. A su vez, para Benjamin la traducción "es ante todo una forma. Para comprenderla de este modo es preciso volver al original, ya que en él está contenida su ley [...]" (BENJAMIN, 1994, p. 286) y no debe tener en cuenta al lector como su destinatario final. Para él la traducción debe "encontrar en la lengua a la que se traduce una actitud que pueda despertar en dicha lengua un eco del original" (p. 291), o en las palabras de Mauri Furlan, "debe traer a la forma de su propia lengua el modo de significar del original" (FURLAN, 1996, p. 101. Traducción mía).

Cabe mencionar que esta breve pincelada teórica, que no está en el centro de este comentario, no resulta la más adecuada a priori —es decir, no emprendí la traducción tomando con estas nociones como modelo a seguir-, sino que surge entre las posturas posibles tras una aproximación crítica que se conforma a lo largo de la traducción —o, según Berman, desde la pre-traducción (BERMAN, 2002, p. 279)— y toma contornos más definidos durante el proceso de revisión. Esto se aplica a los aspectos textuales del texto traducido y que fueron comentados anteriormente, inclusive la percepción y análisis de lo fantástico o maravilloso en el cuento: evidentemente, existen condicionantes apriorísticos más generales de la traducción, como el hecho de tratarse de un texto literario, de un texto de un autor canónico y de que ese autor sea Machado de Assis, que dispone de una fortuna crítica tal que despierta algunas expectativas previas acerca de su estilo, etc. De Machado de Assis se puede decir en su medida lo que dijo Borges de los libros famosos: que su primera lectura ya es la segunda (BORGES, 1983, p. 90). Aún así, el texto sorprende, defraudando de cierto modo esas condicionantes en la medida en que, genéricamente, el cuento tiene un formato peculiar, fuertemente marcado por el género dramático.

De hecho, la adecuación de la atención hacia los detalles formales del texto se explica precisamente por su carácter literario: acompañando a Benjamin, esta traducción es la búsqueda de un eco de la eficacia literaria del texto de Machado. Otros abordajes serán posibles, sin dudas. Quise expresar solamente algunos pensamientos que se desprenden de mi experiencia de traducir "Viver!".

Pablo Cardellino Soto

Universidade Federal de Santa Catarina

pabloufs@@gmail.com 


\section{Referências}

BARRENECHEA, Ana María. Ensayo de una Tipología de la Literatura Fantástica. Revista Iberoamericana, jul-sep, 1972.

BENJAMIN, Walter. La tarea del traductor. [Por: H. P. Murena]. In: VEGA, Miguel Ángel (Ed.). Textos clásicos de teoría de la traducción. Madrid: Ediciones Cátedra, 1994.

BERMAN, Antoine. A prova do estrangeiro. [Por: Maria Emília Pereira Chanut]. Bauru, SP: Edusc, 2002.

- A tradução e a letra on O albergue do longinquo. [Por: Marie-Hélène Catherine Torres, Mauri Furlan \& Andréia Guerini]. Rio de Janeiro: 7 Letras/PGET, 2007.

BORGES, Jorge Luis. Las versiones homéricas. Discusión. $3^{\mathrm{a}}$ ed. Madrid: Alianza Editorial, 1983 ( $1^{\text {a }}$ ed. 1976). Texto publicado originalmente en La Prensa, de Buenos Aires, el 8 de mayo de 1932.

CASCUDO, Luís da Câmara. O judeu errante. Jangada Brasil. Disponible en: < http://www.jangadabrasil.com.br/abril32/im32040c.htm $>$. Reproducido de: CASCUDO, Luís da Câmara. Dicionário do folclore brasileiro. Rio de Janeiro, Ministério da Educação e Cultura / Instituto Nacional do Livro, 1954

FURLAN, Mauri. A missão do tradutor: Aspectos da concepção benjaminiana de linguagem e de tradução. Cadernos de Tradução, n. 1. Florianópolis: G. T. de Tradução/UFSC: 1996. Marie-Hélène Catherine Torres, Mauri Furlan, Walter Carlos Costa (Orgs.).

GUERINI, Andréia y COSTA, Walter. Colocação e qualidade na poesia traduzida. Tradução em revista, n. 3, 2006. Disponible en $<\underline{\text { http://www.maxwell.lambda.ele.puc- }}$

rio.br/acessoConteudo.php?nrseqoco $=28843>$. Acceso el 23/02/2010).

MACHADO DE ASSIS, Joaquim Maria. Várias histórias. Rio de Janeiro: W. M. Jackson Editores, 1937. [s.f.]. Varias historias. Traducción de Rafael Mesa López. Paris: Garnier Hnos,

TODOROV, Tzvetan. Introducción a la literatura fantástica. [Por: Silvia Delpy]. $2^{\mathrm{a}}$ ed. México, DF: Premia, 1981. 